While in Canada, Sir Kenneth took an active part in the work of the Canadian Branch of the International Law Association, in particular addressing meetings of the Toronto Section in 1965 on the special Soviet international law concept of "Peaceful Coexistence," and of the Montreal Section in 1967 on the Chicago Convention and the Freedom of the Air.

EdWARd MaWhinNey

Professor of Law, and Director of International and Comparative Legal Studies, University of Indiana, Indianapolis.

\title{
Wolfgang Gaston Friedmann
}

It is appropriate for Canadian international lawyers to mark the recent death of a good friend and inspiring colleague, Wolfgang Friedmann.

It is not necessary to review the details of Wolfgang Friedmann's many contributions to the development of legal science. We know that he taught in a number of countries and greatly influenced a generation of students. My own experience as a law student in his courses on jurisprudence, comparative law and international law altered the course of my life. Clearly, his impact on many others who came into contact with his work was comparable.

Over a period of more than forty years he published a lengthy list of books and articles which demonstrated his amazing intellectual range, perception and foresight. So remarkable was his comprehension and novel insight that we could almost take it for granted when a reviewer termed one of his treatises "one of the great legal works of the present century."

He was no ivory tower academic but involved himself as an adviser to (and frequent critic of) many governments, international organizations and private groups. There is tragic irony in the circumstances of his death, since he had been a leader in the efforts to establish a satisfactory relationship between his university and the surrounding community. That casual violence should end the life of such a humane man, a dedicated champion of the disadvantaged, adds to our sorrow. 
We in Canada have good reason to think of Wolfgang Friedmann as our close friend. Not only had he lived and worked here for some years; he expressed an interest during the past year or two in taking up residence here again. Almost without exception he managed to find time and energy to accede to our requests for his involvement in our scholarly endeavours.

In the past eighteen months he had visited Toronto to give several lectures to my students, had contributed a chapter to a volume of essays soon to be published in Canada, had attended editorial meetings in Ottawa and Montreal, had visited the Dalhousie campus last spring and was scheduled to lecture there again in October, and was to spend a month in Toronto later in the year to lecture and prepare a short monograph for publication in Canada. He had also agreed to participate in the first annual meeting of the Canadian Council on International Law at Ottawa in October and would have added greatly to the value of the discussions there.

When I spoke to him on the telephone a few hours before his fatal encounter with his assailants, he was as full of enthusiasm and youthful vigour as ever, eager to initiate new scholarly projects. Obviously he had an affection for us in Canada which we heartily reciprocated.

We mourn the death of a true friend, a brilliant and prolific scholar, a wise and compassionate man.

Gerald L. Morris Faculty of Law, University of Toronto 